\title{
Pathophysiology \& Management of Anemia in Cancer Patients: A Systematic Review
}

\author{
Nanda Siddhartha ${ }^{1}$, Ramesh Mathumitha ${ }^{2}$ and Biplab Misra ${ }^{2 *}$ \\ ${ }^{1}$ Radiation Oncology, Associate professor, Department of Radiation Oncology, All India Institute of Medical Sciences, Raipur, Chhattisgarh, India \\ ${ }^{2}$ Radiation Oncology, Senior resident, Department of Radiation Oncology, All India Institute of Medical Sciences, Raipur, Chhattisgarh, India
}

Submission: June 03, 2019; Published: June 27, 2019

"Correspondence Author: Biplab Misra, Radiation Oncology, All India Institute of Medical Sciences, Great Eastern Rd, opposite to Tatibandh, Gurudwara, Raipur, Chhattisgarh 492099, India

\begin{abstract}
Anemia is a common challenge among oncologists. Anemia has been directly implicated in the prognosis of cancer patients. Furthermore, correction of anemia-related symptoms can significantly improve the quality of life in these patients. We performed a systematic review of literature to improve our present knowledge on anemia in cancer patients. The data for review were identified by searching PubMed and Google Scholar and based on the recommendations from professional compendiums such as those by the National Comprehensive Cancer Network and European Society of Medical Oncology. The level of Hemoglobin is an established prognostic factor in many cancer patients. One of the reasons for this is that anemia will result in hypoxia and, subsequently, in tumor resistance to chemotherapy and radiotherapy. This review suggests that the ESAs (Erythropoietin Stimulating Agents) and intravenous iron should be used to maintain target hemoglobin level of $10 \mathrm{~g} / \mathrm{dl}$ while the patient is receiving chemotherapy. However, long-term effect of intravenous iron treatment, ESAs use, and red blood cell transfusions should be further investigated.
\end{abstract}

Keywords: Anemia; Cancer; Erythropoietin-Stimulating Agents; Iron; Transfusion

\section{Introduction}

Anemia remains a challenge among oncologists. The prevalence of anemia in cancer patients ranges from 30\% to $90 \%$ [1]. Based on the common toxicity criteria of the National Cancer Institute (NCI) (1999), hemoglobin (Hb) level of $10 \mathrm{~g} / \mathrm{dl}$ to less than the lower limit of normal was defined as mild, level of 8 to $<10 \mathrm{~g} / \mathrm{dl}$ as moderate, level of 6.5 to $<8 \mathrm{~g} / \mathrm{dl}$ as severe anemia, and level of $<6.5 \mathrm{~g} / \mathrm{dl}$ as life threatening. The level of $\mathrm{Hb}$ is an established prognostic factor in the many cancer patients [2]. One of the reasons is that anemia will result in hypoxia, which stimulates angiogenesis and changes in gene expression leading to tumor growth and spread. These hypoxic cells in tumors can result in tumor resistance to chemotherapy and radiotherapy [3]. Furthermore, correction of anemia can significantly improve the quality of life in these patients [4]. As there is limited number of review articles summarizing the phenomenon of anemia in malignancy, we aimed to perform a systematic review of literature to improve our present knowledge and address the critical gaps in knowledge related to anemia in cancer patients.

\section{Discussion}

\section{Etiology}

The cancer itself can cause anemia. A European Cancer Anemia Survey (ECAS) reported that 30.4\% breast cancer, 49.1\% gynecological cancer, and 32\% non-Hodgkin's lymphoma patients were anemic at the time of enrollment [5,6]. Apart from bone marrow infiltration or metastasis, profuse bleeding from the tumor site or associated loss of appetite causes nutritional deficiency leading to anemia. Another peculiar finding is the red cell aplasia, which is very common among patients diagnosed with thymoma, lymphoma, leukemia, and myeloid metaplasia.

Antimetabolite drugs such as methotrexate and pemetrexed can cause megaloblastic anemia. Immune-mediated hemolysis is a potential complication of some of the monoclonal antibodies such as nivolumab [7], ipilimumab, and pembrolizumab [8]. Platinum-containing drugs can cause anemia through myelosuppression and antibody-mediated destruction of red blood cells (RBCs) and due to its nephrotoxic action. This action 
on kidneys can cause reduction in release of erythropoietin, which decreases the Hb levels [9]. Pentostatin has also been reported to cause hemolytic anemia [10]. Carmustine and doxorubicin have been reported to cause hemolysis in the glucose-6-phosphate dehydrogenase deficient patients [11].

Radiotherapy to the skeletal system can also result in anemia. Approximately $83 \%$ of chronic myeloid leukemia patients and $94 \%$ of gastrointestinal stromal tumor patients treated with imatinib had demonstrated some degree of anemia in the course of their treatment due to inhibition of tyrosine kinase domain of erythropoietin leading to decreased erythropoiesis. Approximately $44 \%$ patients treated with sunitinib also demonstrated anemia [12]. Androgen deprivation therapy may also lead to mild to moderate anemia.

\section{Pathophysiology}

If the cancer arises from the hematopoietic progenitor cell, the blast cells swarm the bone marrow. Consequently, the normal erythroid burst-forming units and stem cell factors are hindered from maintaining the differentiation and growth of RBCs. In cases of solid tumors, the chronic inflammatory infiltrates such as interleukin-6 induce the production of hepcidin in the liver. Hepcidin decreases the iron absorption from the bowel and prevent normal utilization of iron resulting in iron sequestration in the marrow. This phenomenon reduces RBC production and survival [13]. Such anemia is associated with $<20 \%$ saturation of transferrin, ferritin levels of $<100 \mathrm{ng} / \mathrm{ml}$, and a low reticulocyte $\mathrm{Hb}$ concentration of $<32 \mathrm{pg}$. Tumor necrosis factor alpha has an inhibitory effect on GATA-1, which is an essential erythroid transcription factor [14]. Moreover, hypersplenism, which is frequent in myeloproliferative and lymphoid malignancy, can cause anemia by increased destruction of RBCs. Autoimmune hemolytic anemia can occur because of cancer itself, such as reticuloendothelial cancer, chronic lymphatic leukemia, and lymphomas. It is also occurs in patients with multiple myeloma and thymoma.

\section{Evaluation}

According to National Comprehensive Cancer Network (NCCN), Hb level $<11 \mathrm{~g} / \mathrm{dl}$ or a decrease in $\mathrm{Hb}$ levels $>2 \mathrm{~g} / \mathrm{dl}$ below baseline $(12 \mathrm{~g} / \mathrm{dl}$ in women and $<13 \mathrm{~g} / \mathrm{dl}$ in men) requires further evaluation. This involves detailed clinical history analysis including the type (solid cancers or hematological cancers), stage, treatment received, and any family history or past history of anemia along with any comorbidities such as cardiac disease, chronic pulmonary disease, or cerebrovascular disease. Baseline $\mathrm{Hb}$ level before diagnosis should be recorded. Surgical procedures either for diagnosis, staging, or treatment may cause blood loss resulting in anemia. Gastrointestinal or genitourinary bleeding either from primary lesion or the metastatic lesion contributes to iron deficiency.

\section{Laboratory Testing}

In peripheral smear examination, the red cell indices such as mean corpuscular volume and mean corpuscular $\mathrm{Hb}$ concentration are tested. Low reticulocyte level is common in cancer patients with anemia. Increase in reticulocyte and polychromasia count in peripheral smear examination suggests bleeding or hemolysis. In such cases, direct antiglobulin test, disseminated intravascular coagulation (DIC) panel, haptoglobin test, bilirubin test, and lactate dehydrogenase (LDH) test are performed to confirm hemorrhage. If gastrointestinal tract hemorrhage is suspected, upper gastrointestinal endoscopy should be performed. The kidney function should be evaluated if the glomerular filtration rate is $<60 \mathrm{ml} / \mathrm{min} / 1.73 \mathrm{~m} 2$ for $\geq 3$ consecutive months. Hormonal dysfunction should be evaluated to rule out conditions such as hypogonadism, adrenal dysfunction, and hyper/hypothyroidism.

Normocytic normochromic anemia is the commonest type of anemia encountered in cancer patients. Microcytic hypochromic anemia is a common presentation in Hodgkin's lymphoma, nonHodgkin's lymphoma, and renal cell carcinoma. Iron deficiency anemia is usually defined by two important parameters: ferritin level $<30 \mathrm{ng} / \mathrm{ml}$ and transferrin saturation $<15 \%$. Usually, serum ferritin levels $<30 \mathrm{ng} / \mathrm{ml}$ indicates absolute iron deficiency. However, for patients with inflammation or cancer, the cut-off value of ferritin is increased to $100 \mathrm{ng} / \mathrm{ml}$. The bone marrow iron stores are confirmatory evidence of iron deficiency. However, ferritin level is still used to distinguish absolute iron deficiency from functional iron deficiency in clinical practice.

\section{Management}

According to the 2018 NCCN [15] and 20107 European Society for Medical Oncology (ESMO) guidelines [16],

i. The first step is to correct all possible underlying causes other than the cancer-related anemia.

ii. Symptomatic treatment must be provided to patients with cancer-related anemia.

iii. Erythropoietin-stimulating agents (ESAs) are used in patients with $\mathrm{Hb} \leq 10 \mathrm{~g} / \mathrm{dl}$ to increase $\mathrm{Hb}$ levels or prevent further decline.

iv. ESAs should not be used in patients undergoing curative intent therapy.

v. ESAs are not indicated in patients who did not undergo chemotherapy.

vi. Patients undergoing chemotherapy especially with platinum containing drugs benefit from ESA treatment.

vii. The lowest possible dose of ESA should be used to avoid transfusion. 


\section{Cancer Therapy \& Oncology International Journal}

Nutritional deficiency should be corrected before consideration of ESA as per NCCN and ESMO recommendations. A case report by Breen et al. found that patients' response to ESA is reduced in the presence of vitamin B12 deficiency or folate deficiency [17]. Patients with serum vitamin B12 concentration $\leq 210 \mathrm{pg} / \mathrm{ml}$ require vitamin B12 treatment (with an oral dose of 2,000 mcg/day for 3 months) followed by measurement of vitamin B12 value. When the patient's serum folate concentration is $\leq 3.4 \mathrm{ng} / \mathrm{ml}$, folic acid is administered (with an oral dose of 1 $\mathrm{mg} /$ day for 3 months). The functional iron deficiency is caused by insufficient utilization of iron stores. Several published studies showed that intravenous iron treatment is better than oral iron treatment [18]. A study evaluated the effectiveness of $200 \mathrm{mg}$ of intravenous iron sucrose in 64 patients with gynecological cancers. Patients were administered intravenous iron after each course of chemotherapy for six cycles. Results showed that the need for blood transfusion was reduced to $28.1 \%$ with parenteral iron, and $56.3 \%$ patients required transfusion with oral iron [19].

Henry et al. compared the effectiveness of oral iron therapy and intravenous iron therapy in 187 cancer induced anemia patients who received chemotherapy. They found that intravenous iron therapy was superior to oral iron therapy [20]. A systemic review and meta-analysis of randomized controlled trials including 11 trials with 1,681 patients showed drastic increase in hematopoietic response when intravenous iron was administered along with ESAs [21]. By contrast, Steensma et al. found no additional benefit with the use of intravenous iron along with ESA [22]. However, some previous studies revealed that this is because the average transferrin saturation of the patients assigned to intravenous iron arm was $22.5 \%$, which was greater than the threshold required for functional iron deficiency. Auerbach et al. studied the effectiveness of erythropoietin without iron, with oral iron, or with intravenous iron dextran in patients receiving chemotherapy, with a total dose of 2,000 mg over the study period. The intravenous iron was withheld when ferritin level reached $>1,000 \mathrm{ng} / \mathrm{ml}$ and reinstated when it reduced to $<800 \mathrm{ng} / \mathrm{ml}$. Approximately $82 \%$ patients had $\mathrm{Hb}$ levels $>11 \mathrm{~g} / \mathrm{dl}$ in this study [23].

According the NCCN guidelines [15], intravenous iron treatment alone is recommended in patients with absolute iron deficiency anemia, while intravenous iron with ESA is recommended in patients with functional iron deficiency and cancer-related anemia. Adverse effects include nausea, vomiting, hypertension, pruritus, dizziness, and headache. Some studies do not recommend the administration of iron preparation in patients with active infection as the microorganism may utilize the iron for its own growth. Murray et al. demonstrated that there was increased incidence of certain infections after iron repletion in iron deficiency anemia patients [24]. Packed RBCs (PRBCs) are the preferred blood product for transfusion to correct anemia. The hematocrit value of one bag is about $50 \%$ -
$80 \%$ and contains $42.5 \mathrm{~g}-80 \mathrm{~g}$ of $\mathrm{Hb}$ (with $147-278 \mathrm{mg}$ of iron) or $128 \mathrm{ml}$ of pure RBCs. The major benefit of PRBC transfusion is immediate increase in the $\mathrm{Hb}$ level. One unit of PRBC will increase $\mathrm{Hb}$ levels by $1 \mathrm{~g} / \mathrm{dl}$ and hematocrit by $3 \%$ in patients who are not actively bleeding [25].

\section{Conclusion}

Some previous studies showed that patients receiving blood transfusion to increase $\mathrm{Hb}$ level showed an improvement in survival [26]. The risk of transfusion include transfusion-related reactions, congestive heart failure, bacterial contamination and viral infection, increased thrombotic events, and iron overload. Pre-storage leukoreduction has significantly reduced the most common side effect, which is febrile nonhemolytic transfusion reaction. Khorana et al. [27] demonstrated an increase in venous thromboembolism, arterial thromboembolism, and mortality in these cancer patients who received transfusion. However, patients receiving transfusion only during the chemotherapy treatment ( $<1$ year) have lesser risk of iron overload. Overall, the benefits of transfusion outweigh the drawbacks.

ESAs are synthetic human recombinant erythropoietin that can stimulate erythropoiesis. There are mainly two ESA agents: erythropoietin alpha and darbepoetin alpha. Compared with transfusion, the main drawback of ESA treatment is that it will take weeks to increase the Hb level. However, repeated administration of ESAs can maintain the required $\mathrm{Hb}$ levels and can reduce the need for transfusion especially in patients undergoing chemotherapy. A Cochrane-based systematic review of 91 trials with 20,102 patients showed clinically significant reduction in the need for $\mathrm{RBC}$ transfusions in patients who received ESAs. ESA treatment is always initiated using the lowest dose; the dose is doubled if the $\mathrm{Hb}$ level does not increase by $>1$ $\mathrm{g} / \mathrm{dl}$ even after 4 weeks of treatment. In such cases, functional iron deficiency should be excluded before doubling the dosage. Littlewood etal. [28] used erythropoietinalpha and demonstrated a decrease in the need for blood transfusion and an increase in $\mathrm{Hb}$ level by $2.2 \mathrm{~g} / \mathrm{dl}$ vs $0.5 \mathrm{~g} / \mathrm{dl}$ in the placebo arm. A doubleblinded randomized controlled study used darbepoetin alpha $2.25 \mathrm{mcg} / \mathrm{kg} /$ week and $60 \%$ patients achieved hematological response compared with the placebo group [29].

In 2007, several regulatory actions were taken by the Food and Drug Administration (FDA) for both erythropoietin and darbepoetin alpha. They introduced a "black box" warning in the label and risk evaluation and mitigation strategy, which was later withdrawn in 2017 by the NCCN after detailed FDA investigation. This was based on eight randomized trials on the use of ESA in advanced breast cancer, cervical cancer, head and neck cancer, lymphoma, and non-small cell lung cancer, which showed decreased survival in these patients [29-36]. Consequently, the ESA treatment is aimed at increasing the $\mathrm{Hb}$ level by $10 \mathrm{~g} / \mathrm{dl}$.

The PREPARE trial [30] initially showed increased death in breast cancer patients receiving darbepoetin alpha compare 


\section{Cancer Therapy \& Oncology International Journal}

with those not receiving any darbepoetin alfa. However, there was an update to this study, which indicated that there was no difference in the overall survival and the disease-free survival was reduced, but the reduction was not statistically significant [37]. On the contrary, some previous meta-analytic studies $[38,39]$ showed that ESA had no significant effect on mortality or disease progression. A retrospective analysis of 56,210 patients from the Surveillance, Epidemiology, and End Results database (1991-2002), who were diagnosed with colon, non-small cell lung, breast cancer, or diffuse large B-cell lymphoma and treated with chemotherapy, was conducted. This analysis showed similar overall survival with or without ESA [40]. Some previous studies suggested that erythropoietin may antagonize antiHER2 therapy in breast cancer via the JAK2-mediated signaling pathway [41]. However, in animal tumor models, erythropoietin did not enhance tumor growth or affect mortality [42].

Glaspy et al. investigated six trials, which showed an increased risk of thromboembolism in patients receiving ESAs [38]. Meanwhile, an increased incidence of stroke was found in patients with chronic kidney disease treated with darbepoetin alpha [43]. The other risk factors of thromboembolism such as hypercoagulable state, immobilization, recent surgery, use of hormonal therapy, and use of steroids should be excluded before starting the ESAs. Patients receiving ESAs are still at risk of pure red cell aplasia, although the risk is relatively small [44]. This is characterized by low reticulocyte count, loss of bone marrow erythroblast, neutralizing antibodies against erythropoietin, and resistance to ESA therapy (Table 1).

Table 1: Correcting Iron deficiency.

\begin{tabular}{|c|c|}
\hline \multicolumn{2}{|c|}{$\begin{array}{l}\text { Absolute Iron Deficiency; Transferrin Saturation(TSAT) }<20 \% \\
\text { and Ferritin }<30 \mathrm{ng} / \mathrm{ml}\end{array}$} \\
\hline Intravenous iron (preferred) & Oral iron \\
\hline \multicolumn{2}{|c|}{$\begin{array}{l}\text { Functional Iron Deficiency (TSAT } 20 \%-50 \% \text { or ferritin } 30-800 \\
\qquad \mathrm{ng} / \mathrm{ml} \text { ) }\end{array}$} \\
\hline Intravenous iron alone & Intravenous iron + ESAs \\
\hline \multicolumn{2}{|c|}{$\begin{array}{c}\text { Possible Iron Deficiency (ferritin }>500-800 \mathrm{ng} / \mathrm{ml} \text { and TSAT } \\
<50 \% \text { ) }\end{array}$} \\
\hline \multicolumn{2}{|c|}{ Consider intravenous iron in selected patients } \\
\hline \multicolumn{2}{|c|}{ 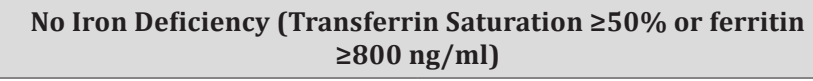 } \\
\hline \multicolumn{2}{|c|}{ ESAs } \\
\hline \multicolumn{2}{|c|}{ Hemoglobin $<7-8 \mathrm{~g} / \mathrm{dl}$} \\
\hline RBC & sion \\
\hline
\end{tabular}

This is significant in chronic kidney disease patients who are receiving subcutaneous ESAs. Hence, caution should be taken when a patient no longer responds to ESAs as well as develop severe anemia. These patients should be further evaluated and ESAs should be discontinued immediately in these patients. ESAs require at least 2 weeks of treatment before evaluation of $\mathrm{Hb}$ level. Parenteral iron should be considered if $\mathrm{Hb}$ level does not increase within 4 weeks. If the patient does not respond to the ESA after 8-9 weeks of treatment, transfusion must be considered. ESAs should be discontinued if $\mathrm{Hb}$ level reaches $11 \mathrm{~g} / \mathrm{dl}$ or when chemotherapy is completed preferably within 6 weeks. The Dosage of different ESAs are shown in Table 2. This review suggests that the long-term effect of intravenous iron treatment, ESA treatment, and RBC transfusions should be investigated further. Moreover, ESAs and intravenous iron should be administered in patients receiving chemotherapy to maintain the target $\mathrm{Hb}$ concentration.

Table 2: Dosage of ESAs.

\begin{tabular}{|c|c|c|}
\hline ESA & Dosage Regimen & $\begin{array}{l}\text { Other Extended } \\
\text { Regimen }\end{array}$ \\
\hline Erythropoietin alpha & $\begin{array}{c}150 \mathrm{IU} / \mathrm{kg} \text { three } \\
\text { times per week } \\
\text { or } 450 \mathrm{IU} / \mathrm{kg} \\
\text { subcutaneously (SC) } \\
\text { once a week }\end{array}$ & $\begin{array}{c}\text { include } 80,000 \text { U SC } \\
\text { every } 2 \text { weeks or } 1 \text {, } \\
20,000 \text { U once every } \\
3 \text { weeks }\end{array}$ \\
\hline Erythropoietin beta & $\begin{array}{c}30000 \text { IU SC ( } 450 \mathrm{IU} / \\
\mathrm{kg} \text { once a week or } \\
3-7 \text { times a week) }\end{array}$ & \\
\hline Erythropoietin theta & $\begin{array}{c}20000 \text { IU SC } \\
\text { (irrespective of body } \\
\text { weight) once a week }\end{array}$ & \\
\hline Erythropoietin zeta & $\begin{array}{c}450 \mathrm{IU} / \mathrm{kg} \text { SC once } \\
\text { a week or } 150 \mathrm{IU} / \\
\mathrm{kg} \mathrm{SC} \text { three times a } \\
\text { week }\end{array}$ & \\
\hline Darbepoetin alpha & $\begin{array}{c}2.25 \mathrm{mcg} / \mathrm{kg} / \text { week } \\
\text { or } 500 \mathrm{mcg} \text { every } 3 \\
\text { weeks }\end{array}$ & $\begin{array}{c}100 \mathrm{mcg} \text { per week, } \\
200 \mathrm{mcg} \text { biweekly, or } \\
300 \mathrm{mcg} \text { three times } \\
\text { a week }\end{array}$ \\
\hline
\end{tabular}

\section{References}

1. Knight K, Wade S, Balducci L (2004) Prevalence and outcomes of anemia in cancer: a systematic review of the literature. Am J Med 116: $11-26$.

2. Caro JJ, Salas M, Ward A, Goss G (2001) Anemia as an independent prognostic factor for survival in patients with cancer. Cancer 91: 22142221.

3. Harrison L, Blackwell K (2004) Hypoxia and anemia: factors in decreased sensitivity to radiation therapy and chemotherapy? Oncologist 9: 31-40.

4. Cortesi E, Gascón P, Henry D, Littlewood T, Milroy R, et al. (2005) Standard of care for cancer-related anemia: improving hemoglobin levels and quality of life Oncologist 68: 22-32.

5. Ludwig H (2007) anemia in patients with cancer. Recombinant Human Erythropoietin (rhEPO) in Clinical Oncology: Scientific and Clinical Aspects of Anemia in Cancer 19: 189.

6. Groopman JE, Itri LM (1999) Chemotherapy-induced anemia in adults: incidence and treatment. J Natl Cancer Inst 91: 1616-1634.

7. Palla AR, Kennedy D, Mosharraf H, Doll D (2016) Autoimmune hemolytic anemia as a complication of nivolumab therapy. Case Rep Oncol 9: 691-697.

8. Nair R, Gheith S, Nair SG (2016) Immunotherapy-associated hemolytic anemia with pure red-cell aplasia. N Engl J Med 374: 1096-1097.

9. Wood PA, Hrushesky WJ (1995) Cisplatin-associated anemia: an erythropoietin deficiency syndrome. J Clin Invest 95: 1650-1659. 


\section{Cancer Therapy \& Oncology International Journal}

10. Byrd JC, Hertler AA, Weiss RB, Freiman J, Kweder S, et al. (1995) Fatal recurrence of autoimmune hemolytic anemia following pentostatin therapy in a patient with a history of fludarabine-associated hemolytic anemia. Ann Oncol 6: 300-301.

11. Sagone AL, Burton GM (1979) The effect of BCNU and adriamycin on normal and G6PD deficient erythrocytes. Am J Hematol; 7: 97-106.

12. Barni S, Cabiddu M, Guarneri P, Lonati V, Petrelli F (2012) The risk for anemia with targeted therapies for solid tumors. Oncologist 17: 715724.

13. Gilreath JA, Stenehjem DD, Rodgers GM (2014) Diagnosis and treatment of cancer-related anemia. Am J Hematol 89: 203-212.

14. Dicato M, Plawny L, Diederich M (2010) Anemia in cancer. Ann Oncol 21: 167-172.

15. Rodgers GM 3rd, Becker PS, Bennett CL, Cella D, Chanan-Khan A, et al. (2008) Cancer- and chemotherapy-induced anemia. J Natl Compr Canc Netw 6: 536-564.

16. Schrijvers D, De Samblanx H, Roila F (2010) ESMO Guidelines Working Group. Erythropoiesis-stimulating agents in the treatment of anaemia in cancer patients: ESMO Clinical Practice Guidelines for use. Ann Oncol 21: 244-247.

17. Breen CP, Macdougall IC (1999) Correction of epoetin-resistant megaloblastic anaemia following vitamin B12 and folate administration. Nephron 83: 374-375.

18. Aapro M, Österborg A, Gascón P, Ludwig H, Beguin Y (2012) Prevalence and management of cancer-related anaemia, iron deficiency and the specific role of IV iron. Ann Oncol 23: 1954-1962.

19. Athibovonsuk P, Manchana T, Sirisabya N (2013) Prevention of blood transfusion with intravenous iron in gynecologic cancer patients receiving platinum-based chemotherapy. Gynecol Oncol 131: 679-682.

20. Henry DH, Dahl NV, Auerbach M, Tchekmedyian S, Laufman LR (2007) Intravenous ferric gluconate significantly improves response to epoetin alfa versus oral iron or no iron in anemic patients with cancer receiving chemotherapy. Oncologist 12: 231-242.

21. Gafter-Gvili A, Rozen-Zvi B, Vidal L, Leibovici L, Vansteenkiste J, et al. (2012) Intravenous iron supplementation for the treatment of chemotherapy-induced anaemia - systematic review and metaanalysis of randomised controlled trials. Acta Oncol 52: 18-29.

22. Steensma D, Sloan J, Dakhil S, Dalton R, Kahanic S, et al. (2011) Phase III, randomized study of the effects of parenteral iron, oral iron, or no iron supplementation on the erythropoietic response to darbepoetin alfa for patients with chemotherapy-associated anemia. J Clin Oncol 29: $97-105$

23. Auerbach M, Ballard H, Trout J, Mcllwain M, Ackerman A, et al. (2004) Intravenous iron optimizes the response to recombinant human erythropoietin in cancer patients with chemotherapy-related anemia: a multicenter, open-label, randomized trial. J Clin Oncol 22: 13011307.

24. Murray MJ, Murray AB, Murray MB, Murray CJ (1978) The adverse effect of iron repletion on the course of certain infections. Br Med J 2 . 1113-1115.

25. Wiesen A, Hospenthal DR, Byrd JC, Glass KL, Howard RS, et al. (1994) Equilibration of hemoglobin concentration after transfusion in medical inpatients not actively bleeding. Ann Intern Med 121: 278-330.

26. Snyder CW, Weinberg JA, McGwin G, Melton SM, George RL, et al. (2009) The Relationship of Blood Product Ratio to Mortality: Survival Benefit or Survival Bias? J Trauma 66: 358-364.

27. Khorana AA, Francis CW, Blumberg N, Culakova E, Refaai MA, et al. (2008) Blood transfusions, thrombosis, and mortality in hospitalized patients with cancer. Arch Intern Med 168: 2377-2381.
28. Littlewood T], Bajetta E, Nortier JW, Vercammen E, Rapoport B (2001) Epoetin Alfa Study Group. Effects of epoetin alfa on hematologic parameters and quality of life in cancer patients receiving nonplatinum chemotherapy: results of a randomized, double-blind, placebocontrolled trial. J Clin Oncol 19: 2865-2874.

29. Hedenus M, Adriansson M, Miguel J, Kramer MH, Schipperus MR, et al. (2003) Efficacy and safety of darbepoetin alfa in anaemic patients with lymphoproliferative malignancies: a randomized, double-blind, placebo-controlled study. Br J Haematol 122: 394-403.

30. Untch M, Fasching PA, Bauerfeind I, Conrad U, Camara O, et al. (2008) PREPARE trial. A randomized phase III trial comparing preoperative, dose-dense, dose-intensified chemotherapy with epirubicin, paclitaxel and CMF with a standard dosed epirubicin/cyclophosphamide followed by paclitaxel \pm darbepoetin alfa in primary breast cancer: A preplanned interim analysis of efficacy at surgery. J Clin Oncol 26: 517.

31. Henke M, Laszig R, Rübe C, Schäfer U, Haase K, et al. (2003) Erythropoietin to treat head and neck cancer patients with anaemia undergoing radiotherapy: randomised, double-blind, placebocontrolled trial. Lancet 362: 1255-1260.

32. Leyland-Jones B, Semiglazov V, Pawlicki M, Pienkowski T, Tjulandin S, et al. (2005) Maintaining normal hemoglobin levels with epoetin alfa in mainly nonanemic patients with metastatic breast cancer receiving first-line chemotherapy: a survival study. J Clin Oncol 23: 5960-5972.

33. Overgaard J, Hoff CM, Sand Hansen H, Specht L, Overgaard M, et al. (2007) 6LB Randomized study of the importance of novel erythropoiesis stimulating protein (Aranesp®) for the effect of radiotherapy in patients with primary squamous cell carcinoma of the head and neck (HNSCC) - the Danish Head and Neck Cancer Group DAHANCA 10 randomized trial. Eur J Cancer 5:7.

34. Smith RE, Aapro MS, Ludwig H, Pintér T, Šmakal M, et al. (2008) Darbepoetin alfa for the treatment of anemia in patients with active cancer not receiving chemotherapy or radiotherapy: results of a phase iii, multicenter, randomized, double-blind, placebo-controlled study. J Clin Oncol 26: 1040-1050.

35. Thomas G, Ali S, Hoebers F, Darcy K, Rodgers W, et al. (2008) Phase III trial to evaluate the efficacy of maintaining hemoglobin levels above $12.0 \mathrm{~g} / \mathrm{dL}$ with erythropoietin vs above $10.0 \mathrm{~g} / \mathrm{dL}$ without erythropoietin in anemic patients receiving concurrent radiation and cisplatin for cervical cancer. Gynecol Oncol 108: 317-325.

36. Wright JR, Ung YC, Julian JA, Pritchard KI, Whelan TJ, et al. (2007) Randomized, double-blind, placebo-controlled trial of erythropoietin in non-small-cell lung cancer with disease-related anemia. J Clin Oncol 25: 1027-1032.

37. Untch M, Fasching PA, Konecny GE, von Koch F, Conrad U, et al. (2011) PREPARE trial: a randomized phase III trial comparing preoperative, dose-dense, dose-intensified chemotherapy with epirubicin, paclitaxel and CMF versus a standard-dosed epirubicin/cyclophosphamide followed by paclitaxel \pm darbepoetin alfa in primary breast cancerresults at the time of surgery. Ann Oncol 22: 1988-1998.

38. Glaspy J, Crawford J, Vansteenkiste J, Henry D, Rao S, et al. (2010) Erythropoiesis-stimulating agents in oncology: a study-level metaanalysis of survival and other safety outcomes. Br J Cancer 102: 301315.

39. Ludwig H, Crawford J, Österborg A, Vansteenkiste J, Henry D, et al. (2009) Pooled analysis of individual patient-level data from all randomized, double-blind, placebo-controlled trials of darbepoetin alfa in the treatment of patients with chemotherapy-induced anemia. J Clin Oncol 27: 2838-2847.

40. Hershman D, Buono DL, Malin J, McBride R, Tsai WY, et al. (2009) Patterns of use and risks associated with erythropoiesis-stimulating agents among medicare patients with cancer. J Natl Cancer Inst 101:1633-1641. 


\section{Cancer Therapy \& Oncology International Journal}

41. Liang K, Esteva FJ, Albarracin C, Stemke-Hale K, Lu Y, et al. (2010) Recombinant human erythropoietin antagonizes trastuzumab treatment of breast cancer cells via jak2-mediated src activation and pten inactivation. Cancer Cell 18: 423-435.

42. Österborg A, Aapro M, Cornes P, Haselbeck A, Hayward C, et al. (2007) Preclinical studies of erythropoietin receptor expression in tumour cells: Impact on clinical use of erythropoietic proteins to correct cancer-related anaemia. Eur J Cancer 43: 510-519.
43. Pfeffer MA, Burdmann EA, Chen CY, Cooper ME, de Zeeuw D, et al. (2009) A trial of darbepoetin alfa in type 2 diabetes and chronic kidney disease. N Engl J Med 361: 2019-2032.

44. Bennett C, Luminari S, Nissenson A, Tallman M, Klinge S, et al. (2004) Pure red-cell aplasia and epoetin therapy. N Engl J Med 351: 14031408.

\section{Your next submission with Juniper Publishers will reach you the below assets}

- Quality Editorial service

- Swift Peer Review

- Reprints availability

- E-prints Service

- Manuscript Podcast for convenient understanding

- Global attainment for your research

- Manuscript accessibility in different formats

( Pdf, E-pub, Full Text, Audio)

- Unceasing customer service

Track the below URL for one-step submission https://juniperpublishers.com/online-submission.php 